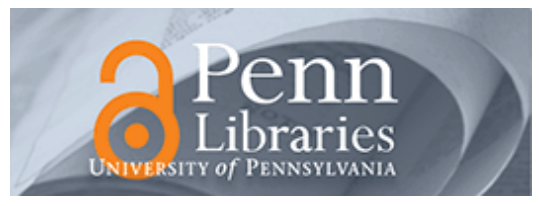

University of Pennsylvania

ScholarlyCommons

Management Papers

Wharton Faculty Research

6-1-2012

\title{
From the Commercial to the Communal: Reframing Taboo Trade- Offs in Religious and Pharmaceutical Marketing
}

\author{
A. Peter McGraw \\ University of Colorado \\ Janet A. Schwartz \\ Tulane University \\ Philip E. Tetlock \\ University of Pennsylvania
}

Follow this and additional works at: https://repository.upenn.edu/mgmt_papers

Part of the Management Sciences and Quantitative Methods Commons

\section{Recommended Citation}

McGraw, A., Schwartz, J. A., \& Tetlock, P. E. (2012). From the Commercial to the Communal: Reframing Taboo Trade-Offs in Religious and Pharmaceutical Marketing. Journal of Consumer Research, 39 (1), 157-173. http://dx.doi.org/10.1086/662070

This paper is posted at ScholarlyCommons. https://repository.upenn.edu/mgmt_papers/242

For more information, please contact repository@pobox.upenn.edu. 


\title{
From the Commercial to the Communal: Reframing Taboo Trade-Offs in Religious and Pharmaceutical Marketing
}

\author{
Abstract \\ Although consumers typically expect organizations to profit from marketing goods and services, they also \\ believe that certain organizations, like those that focus on religion and health, should prioritize communal \\ obligations. Indeed, consumers may find it morally distressing when communally focused organizations \\ use overtly commercial marketing strategies like rebranding or value-based pricing. We demonstrate how \\ moral distress and consumer backlash result from such taboo trade-offs and investigate when \\ communal-sharing rhetoric for religious and pharmaceutical marketing reduces distress. Communal \\ justifications used by communally focused organizations are particularly effective when consumers are \\ not closely monitoring the motives of the organization or when the product is need-based. However, \\ communal justifications become less effective and market-pricing justifications become more effective \\ when consumers are attuned to the persuasive intentions of the organization. Implications for consumer \\ goals are discussed. \\ Disciplines \\ Management Sciences and Quantitative Methods
}


From the Commercial to the Communal:

\title{
Reframing Taboo Trade-offs in Religious and Pharmaceutical Marketing
}

\author{
A. PETER MCGRAW
}

JANET A. SCHWARTZ

PHILIP E. TETLOCK*

\begin{abstract}
*A. Peter McGraw is Assistant Professor of Marketing; University of Colorado, Boulder, Leeds School of Business, UCB 419, Boulder, CO 80309 (peter.mcgraw@colorado.edu). Janet A. Schwartz is an Assistant Professor of Marketing; Tulane University, Freeman School of Business, New Orleans, LA, 70118 (janet.schwartz@tulane.edu). Philip E. Tetlock is the Annenberg University Professor, with appointments in the Wharton School of Business and Psychology Department, at the University of Pennsylvania, Philadelphia, PA, 19104 (tetlock@wharton.upenn.edu). This research was supported by the Princeton University Center for Demography and Aging: NIH grant \# 5 P30 AG024361. Special thanks to Derick Davis, Kelly Herd, Christy Horber, Bridget Leonard and Barry Shapiro for research assistance, and to Christy Horber, Derick Davis, Christina Kan, and Aline Grüneisen for their editorial assistance. We would also like to thank Dan Bartels, Alan Fiske, Elissa Guralnick, Donnie Lichtenstein, Mary Frances Luce, Leaf Van Boven, and the Moral Research Lab (MoRL) for their helpful comments and suggestions.
\end{abstract}


Although consumers typically expect organizations to profit from marketing goods and services, they also believe that certain organizations, like those that focus on religion and health, should prioritize communal obligations. Indeed, consumers may find it morally distressing when communally-focused organizations use overtly commercial marketing strategies like rebranding or value-based pricing. We demonstrate how moral distress and consumer backlash result from such taboo trade-offs and investigate when communal-sharing rhetoric for religious and pharmaceutical marketing reduces distress. Communal justifications used by communallyfocused organizations are particularly effective when consumers are not closely monitoring the motives of the organization or when the product is need-based. However, communal justifications become less effective and market-pricing justifications become more effective when consumers are attuned to the persuasive intentions of the organization. Implications for consumer goals are discussed. 
Although consumers expect organizations to profit from marketing goods and services, they prefer that certain types of organizations abide by communal obligations. Consumers should therefore perceive a normative breach, or a taboo trade-off, when organizations operating within communally-focused domains, like religion and healthcare, rely on commercial marketing strategies like rebranding or value-priced pricing. Commercial marketing that is especially transparent may anger consumers and cause backlash against the organization. We use religious and pharmaceutical marketing as case studies to examine negative response to commercialmarketing in communally-focused domains. We also test the efficacy of rhetorical justifications, which highlight communal aspects of organizational practices, to assuage distress and reduce backlash.

Religious organizations are using commercial marketing techniques to compete with the secular world for the allegiance of worshipers. Because congregants generally believe that a church's purpose is to promote communal endeavors (and not simply recruit paying members), we question whether these strategies undermine the perceived sanctity of religious organizations and gauge the extent to which communally-focused justifications restore that sanctity. Likewise, in the domain of healthcare, consumers tend to favor a communal focus and often endorse the view that medical care should be provided as needed rather than on the ability or willingness to pay. As with religious consumers, healthcare consumers should be distressed by transparent commercial strategies that signal a market approach to patient care. This seems particularly salient for pharmaceuticals and the value-pricing of lifesaving drugs (Gregson, Sparrowhawk, Mauskopf, and Paul 2005). What both types of organizations have in common is that they may successfully justify their behavior by shifting perceptions to communal responsibilities. 
The use of commercial marketing strategies in communal domains has important implications for consumer goals and well-being. Successful commercial marketing strategies may benefit consumers by encouraging religious participation and medication adherence, both of which have been associated with better health and longer life (McCullough and Willoughby 2009). However, if commercial strategies suggest a conspicuous market approach to religion and healthcare, then consumers may be alienated and either disengage or lash out.

In what follows, we present a model that predicts the thoughts, feelings and behaviors that result when commercial marketing strategies appear in communally-focused domains. We then examine the processes by which consumer distress may be rhetorically mitigated.

Fiske's Theory of Social Relations and Taboo Trade-offs by Organizations

Fiske's $(1991,1992)$ social relational theory documents four extensively validated categories of norms that organize our social world (Haslam 2004): communal sharing, authority ranking, equality matching, and market pricing. Our inquiry focuses on the individualist and collectivist endpoints of Fiske's continuum:

Market Pricing (MP): People give and take according to a value or utility metric, typically money, which group members can freely exchange based on cost-benefit analysis of consumer value. The structure underlies capitalism and business transactions.

Communal Sharing (CS): People give as they can and take as they need. Group members are treated as a community and share rights and responsibilities designated by their ability and needs. The structure underlies sharing a commons (e.g., kibbutzim or co-op), family, or other close (e.g., agapic) relationships.

We extend the theory to address interactions of consumers with organizations (March 1994). Although most organizations (profit and non-profit) rely on a market-pricing approach, consumers sometimes believe that organizations ought to be subject to communal-sharing obligations. Prior research shows that organizations can be viewed in non-market terms; a bank, 
for example, can elicit communal expectations based on past communal behavior (Aggarwal 2004), and consumers can view service relationships with restaurants and travel agencies as a friendship (Wan, Hui, and Wyer 2011). These expectations arise because consumers can develop relationships with companies that parallel interpersonal relationships (Fournier 1998).

We explore what happens when consumers desire (and even expect) communal-sharing behavior from an organization but receive market-pricing behavior instead. Actions that extend market-pricing norms into spheres traditionally regulated by communal-sharing norms constitute a taboo trade-off (Fiske and Tetlock 1997; McGraw, Tetlock and Kristel 2003). Empirical evidence identifies two reactions to taboo trade-offs (Rai and Fiske 2011; Tetlock et al. 2000): moral outrage and moral cleansing.

Moral Outrage. The sacred-value-protection model (Tetlock 2002) suggests that taboo trade-offs are disturbing because they reduce sacred values that are meant to be infinitely important, such as faith, dignity or life, to finite monetary values (Baron and Spranca 1997; Tetlock, Peterson, and Lerner 1996). People are quick to criticize those who create taboo tradeoffs. For instance, the public was outraged when they found that the Clinton administration provided major campaign contributors a night's stay in the Lincoln bedroom (McGraw and Tetlock 2005). Consumers become similarly distressed when companies that foster a communal relationship revert to market-pricing, such as charging fees for simple requests (Aggarwal 2004).

Moral Cleansing. Merely contemplating taboo trade-offs can threaten one's moral identity (Tetlock et al. 2000; Tetlock 2002) and elicit feelings of disgust (Haidt and Algoe 2004). These feelings, in turn, motivate people to morally "cleanse" themselves. For example, people were more likely to volunteer for an organ donation campaign after reading about an administrator's choice between funding a lifesaving operation for a boy and purchasing hospital 
beds (Tetlock et al. 2000). Other moral cleansing acts take the form of backlash - such as boycotts, political lobbying, or negative word of mouth - in an effort to punish communal organizations that adopt commercial strategies. For example, doctors called for a boycott of Abbott Laboratories after finding out about the company's $400 \%$ price increase, which was designed to steer patients to a new HIV drug (Harris 2004).

\section{Relational Framing by Organizations}

Taboo trade-offs are cognitively taxing and emotionally unpleasant; they are aversive states that people prefer to avoid (Gross 1998, 2002; Ehrich and Irwin 2005; Luce, Bettman and Payne 1997; Nowlis, Kahn and Dhar 2002). Thus, consumers who are offered justifications that reframe taboo trade-offs into something less distressing may forgive companies that transgress (Aaker, Fournier, and Brasel 2004; McGraw and Tetlock 2005).

In our inquiry, we explore how organizations reframe their market-pricing strategies into communal-sharing behavior (e.g. "Like a good neighbor, State Farm is there"). Previous research supports our notion that relational framing can assuage distress over market-pricing strategies (Tuk, Verlegh, Smidts, and Wigboldus 2009). For instance, the Clinton administration effectively justified granting favors to campaign donors by invoking the norm of reciprocity: friends (Clintons) returning a favor to friends (donors; Cialdini 2001; McGraw and Tetlock 2005). Similarly, we examine how organizations in religion and healthcare can use communal rhetoric to neutralize negative reactions to commercial marketing strategies.

Organizations offering justifications may successfully manage consumer impressions because consumers' default cognitive reaction is to readily accept justifications, particularly when it is difficult to process information and weigh the credibility of claims (Kunda 1990; Gilbert, Krull, and Malone 1990; Petty and Cacioppo, 1986; Tetlock, 2002; Tuk et al. 2009). 
Insofar as the public is not invested in monitoring church or corporate misconduct, churches and corporations may have considerable latitude to assuaging reactions to apparent norm violations.

\section{RELIGIOUS MARKETING STUDIES}

Religious organizations are increasingly meeting congregant needs with secular marketing techniques (Kenneson and Street 1997; Symonds 2005). The strategic benefits of religious marketing are well-documented (Drucker 1989; Schlesinger and Mellado 1991; Shawchuck, Kotler, Wrenn, and Rath 1992). Megachurches, like the 20,000 member Willow Creek Church, have revamped their offerings based on market-research surveys asking why people do not attend church (Schlesinger and Mellado 1991; Symonds 2005). Some churches employ MBAs or consulting agencies to create strategic marketing plans that address recruiting, atmospherics and customer service, and some synagogues are sending volunteers to supermarkets for Passover outreach and throwing cocktail recruiting parties (Luo 2006).

Successful religious marketing diverges from deeply rooted sentiments - dating back to Martin Luther's campaign against selling indulgences - that the faithful should defend religious principles against secular intrusions (Belk, Wallendorf, and Sherry 1989). Anecdotal evidence also indicates that consumers view religious marketing as a secular-sacred breach.

Churchmarketingsucks.com, for example, presents conspicuous forms of religious marketing: churches raffling Hummer SUVs to promote winter retreats (Graham 2005) or distributing free gasoline vouchers to first-time visitors (Beattie 2005). The academic literature also finds that religious advertising upsets consumers (McDaniel 1986), and the practitioner literature warns that marketing may undermine the sanctity of the church (e.g., Shawchuck et al. 1992). 
How can the apparent effectiveness of religious marketing be reconciled with its potential for denunciation? Our framework proposes that the degree of distress caused by marketing hinges on the congruence between the relational norm ascribed to the organization and the norm ascribed to the strategy. Negative reactions should occur for religious organizations that use commercial marketing (i.e., market-pricing) but not communally-based marketing (i.e., communal sharing). Still, even when strategies have an underlying market focus, organizations may successfully assuage distress by communally reframing the strategy.

\section{Study 1: Religious Marketing Strategies}

Is all religious marketing created equal? We examined whether the acceptability of religious marketing strategies depends on the underlying market-pricing or communal-sharing norms. As a point of comparison, we contrasted the acceptability of strategies intended for a church with those intended for a credit union, a traditionally commercial enterprise.

Prior to the study, we surveyed whether people expected a communal-sharing focus from a church $(N=20)$. All participants endorsed this focus, in which "priorities and offerings (are) based on cooperative and relationship-building principles," over a market-focus, in which "priorities and offerings (are) based on business and economic principles." In contrast, only 15\% endorsed a community-based rule for the credit union.

Method

Thirty-two undergraduates, participating for partial course credit, were randomly assigned to either the church or credit union condition and told that the organization was considering a variety of marketing strategies "to better serve, recruit, and retain members." Nine broad strategies were presented that could be viewed as either communal sharing (e.g., 
establishing child care services) or market pricing (e.g., rebranding; see Table 1). Respondents were asked to judge how acceptable or unacceptable each strategy was from an "ethical, moral, or principled standpoint."

As a manipulation check, sixteen participants were randomly selected from the same population to judge the strategies' relational focus and were told that an organization was considering using the strategies (church or credit union not mentioned). Respondents judged whether each strategy was communal (based on cooperative and relationship-building principles) or market focused (based on business and economic principles) on an eight-point scale, with endpoints "Community Focused" and "Market Focused."

Insert table 1 about here

Results

We first examined the perceived focus (communal sharing vs. market pricing) of the strategies. An inspection of the ratings revealed three categories of responses: three were marketpricing focused $\left(M^{\prime} \mathrm{s}=6.31-6.75\right)$, three were communal-sharing focused $\left(M^{\prime} \mathrm{s}=2.06-2.81\right)$, and three were at the midpoint (M's $=3.69-4.44$; table 1$)$.

Insert figure 1 about here

Judgments of acceptability were also collapsed into three relational-focus categories (see Figure 1). We created a hierarchical regression model to test the effects of relational strategy on judgments of acceptability within participants. We first regressed acceptability judgments on the mean focus of the marketing strategy. For each participant, we calculated an unstandardized beta weight for the effect of the strategy on acceptability. We then regressed these beta weights on the 
condition factor (church or credit union). The model was significant $(F(1,31)=10.9 ; p<.01)$. Although there was no difference in acceptability between the church and credit union conditions $(t(31)=0.8 ; n . s)$, there was a significant effect of condition on the slope $(t(31)=3.3 ; p<.01)$, indicating that the strategy's relational focus influenced acceptability judgments for the church, but not the credit union. A mixed-model ANOVA using the three categorized means for each subject confirmed the hierarchical analysis. The effect of strategy type was significant: communal-sharing strategies were judged as more acceptable than market-pricing strategies $\left(F(2,60)=14.9, p<.001 ; \eta^{2}=.32\right)$. Respondents also rated the strategies as more acceptable for the credit union than the church, although the effect was not significant $(F(1,30)=2.3 ; p<.14$; $\left.\eta^{2}=.07\right)$. The main effects, however, were qualified by a significant two-way interaction $(F(2,60)$ $\left.=4.9, p<.01 ; \eta^{2}=.19\right)$.

\section{Discussion}

The relational focus of a marketing strategy and the nature of the enacting organization interact to affect the strategy's level of acceptance. Although consumers are reluctant to accept commercial strategies, such as religious advertising (McDaniel 1986), we show that consumers approve of marketing when it is congruent with a communal nature. The relational focus of the strategy, however, had little effect on evaluations of the credit union, an organization with a clear commercial focus. Consistent with previous work, participants resisted market-pricing in the communal domain but accepted it elsewhere (Fiske and Tetlock 1997; McGraw et al. 2003).

Behavioral intentions and mediation. The use of commercial-marketing strategies by religious organizations may have negative implications for the organization as well as worshippers. We conducted a brief follow-up study to examine whether perceptions of religious marketing influence willingness to join an organization. Fifty three undergraduates were 
randomly assigned to one of the two most disparate marketing strategies in Table 1: providing childcare to members (CS) or rebranding (MP). After reading about the church's consideration of the strategy, participants indicated their agreement with the statement, "I would find it bothersome if the church would engage in such a practice" on a seven-point scale labeled "Strongly Disagree" to "Strongly Agree." Respondents also judged, on a seven-point scale labeled "Very Likely" to "Very Unlikely" their willingness to join such an organization.

Respondents were more bothered by the market-pricing strategy $(M=4.21)$ than the communal-sharing strategy $(M=2.21 ; t(51)=4.0, p<.001$; Cohen's $d=1.18)$ and less willing to join a religious organization that used the market-pricing strategy $(M=5.82)$ than the communalsharing strategy $(M=4.76 ; t(51)=2.2, p<.05 ; d=.58)$. The degree to which respondents were bothered by the strategy mediated the effect on willingness to join the organizations ( $\mathrm{a} \times \mathrm{b}=.82$, $95 \% \mathrm{CI}=.22$ to 1.51$)$. The direct effect of marketing strategy became non-significant ( $\mathrm{c}=1.05, t$ $=2.20 ; \mathrm{c}^{\prime}=.22, t=.44 ; p>.65$ ), signaling indirect only mediation (Zhao, Lynch, and Chen 2010).

Study 2: Outsourcing Prayer

We next examine reactions to a specific religious marketing strategy, outsourcing prayer, and tested the effectiveness of communal justifications to assuage distress. Although marketing is more commonly employed by non-denominational churches, traditional churches also use religious marketing. Many Catholic churches in the U.S. are unable to fulfill requests for Mass intentions (i.e., request a Mass to be celebrated for a friend or loved one) in a timely manner and have been outsourcing prayer requests to Priests in India (Rai 2004). The practice serves the needs of the congregation with a market-pricing solution: matching supply with demand. The 
congregation can fulfill prayer requests quickly, and poorly funded Indian churches receive a portion of the donation. We suspect that the explicit connection to the well-known marketpricing practice of outsourcing will distress consumers, but that communally justifying the practice will attenuate negative reactions.

Method

One hundred and one undergraduates participated in the study for partial course credit. They learned about the Catholic Church's decision to send Mass (i.e., prayer) requests to a congregation in rural India because local congregations could not keep up with demand. The materials outlined the practice and discussed some of the benefits to both congregations and the congregants (see appendix A). Within the description of the practice was one of three randomly assigned manipulations. Respondents were presented with a communal-sharing justification, a market-pricing justification, or no justification. The communal-sharing justification was:

From the perspective of the Catholic Church everyone is part of God's community. It does not matter to God who says the Mass. Priests, and their congregations for that matter, are undifferentiated in God's eyes.

To test whether a market-pricing justification would influence feelings about the outsourcing prayer policy (Langer, Blank, and Chanowitz 1978), we included the following:

From the perspective of the Catholic Church, it is a simple matter of matching supply and demand in the market for prayer services - and thus maximizing prayers and revenue generation on a worldwide basis.

Respondents then expressed their agreement with two statements measuring their reaction to the policy: 1) I find it bothersome that the Church would engage in such a practice, and 2) The Church is not justified to enact such a policy. The anchors of the seven-point scales were labeled, "Strongly Disagree" and "Strongly Agree." 
One criticism of the evidence for taboo trade-offs is that judgments are subject to socially-desirable responding (Johar 2005; Kahn 2005). To determine whether outsourcing prayer creates real distress, we examine whether consumers react as if they are tainted by taboo trade-offs (Tetlock, 2002). One such response to unethical deeds is to seek out physical cleansing opportunities (Zhong and Liljenquist 2006). To examine physical cleansing due to viewing outsourcing prayer in market-pricing terms, we included an ostensibly unrelated product preference survey for various cleansing products (Dove Shower Soap, Windex Cleaner, Crest Toothpaste, and Tide Laundry Detergent) and non-cleansing products (Sony CD Cases, Post-it Notes, Nantucket Nectars Juice, and Energizer Batteries; Zhong and Liljenquist 2006). Product preferences were measured on a seven-point scale, with the endpoints, "Completely Undesirable" and "Completely Desirable."

Results

The two measures of distress were coded one through seven, where higher numbers indicated greater distress with the policy. The correlated $(r=.67 ; p<.001)$ measures were averaged to form a composite measure. Reactions to the market-pricing justification condition $(M=3.78)$ was not significantly different from the no-justification condition $(M=4.00)$, but reactions to each condition were significantly more distressing than reactions to the communalsharing justification; $(M=2.81 ; \mathrm{t}(66)=3.4, p<.01 ; d=.83$, and $\mathrm{t}(65)=2.6, \mathrm{p}<.05 ; d=.67 ; p<$ .05 , respectively). An ANOVA test of the relational frame manipulation was significant ( $F(1$, $\left.100)=6.2, p<.001 ; \eta^{2}=.11\right)$.

We calculated a difference score of the average ratings of the cleansing and noncleansing products; higher numbers indicated a greater preference for the cleansing products. Because there were no differences in preferences in the market-pricing and no-justification 
conditions, we pooled those responses and compared them to responses in the communal-sharing condition. Consistent with explicit ratings, respondents in the market-pricing and no justification conditions had larger difference scores than those in the communal-sharing justification condition $(M=0.83$ vs. $M=0.35$, respectively; $\mathrm{t}(99)=2.0, p<.05 ; d=.43)$.

\section{Discussion}

Negative reactions to the Catholic Church's use of outsourcing prayer, a market-pricing practice, were assuaged by a communal-sharing justification. A market-pricing justification had no effect on default perceptions of the practice; moral distress with a description of outsourcing that contained no justification was no different from distress after a market-pricing justification. Furthermore, evidence of moral cleansing among consumers exposed to taboo trade-offs suggests they are not simply responding in socially desirable ways but are indeed morally distressed by the practice of outsourcing prayers.

\section{Study 3: Exacerbating Relational Justification Effects}

In order to examine the cognitive processes that underlie the effectiveness of communal justifications, we examined reactions to justifications for outsourcing prayer when processing is impaired. We expected that the justification effects shown in the previous study would be more pronounced when consumers are cognitively busy because they will be inclined to rely on their initial reaction to the rationale (Gilbert, et al. 1990).

\section{Method}

One hundred and ninety three undergraduates participated in the study for partial course credit. They were presented an abbreviated version of the outsourcing stimuli from Study 2 (see 
appendix B). Respondents were randomly assigned to either the communal-sharing justification or the market-pricing justification.

Prior to reading the scenario, participants were also randomly assigned to a low or high cognitive load condition. The low-load condition featured an eight-digit string of the same number, whereas the high-load condition featured an eight-digit string of different numbers (Gilbert and Hixon 1991; Krull, 1993).

We assessed participants' reactions to the policy. We presented respondents with three statements designed to tap into potential feelings of outrage: 1) It is outrageous for the Church to send prayers to India, 2) It distresses me that a religious organization would engage in such a practice, 3) It angers me that the Church would use this practice instead of finding another solution. Respondents indicated their agreement with the statement on a seven-point scale with anchors labeled, "Strongly Disagree” and "Strongly Agree."

Results

Responses to the three distress-related measures were highly correlated $(\alpha=.91)$, so we formed a composite measure of distress by averaging participants' responses. Replicating Study 2, the low-load condition analysis revealed an effect of justification; participants in the communal-sharing justification condition were less distressed $(M=3.08)$ than those in the market-pricing condition $(M=3.69 ; t(96)=1.96, p<.05 ; d=.40$; figure 2$)$. The difference in judgments, however, became more pronounced when participants were under a higher load $\left(M_{\mathrm{CS}}\right.$ $=2.63$ vs. $M_{\mathrm{MP}}=4.13$; the interaction of justification and load was significant; $F(1,192)=4.1, p$ $\left.<.001 ; \eta^{2}=.02 ;\right)$ 
Discussion

The study replicates the effectiveness of a communal-sharing justification of a commercial-marketing strategy. Importantly, the study also shows the justification to become even more effective when consumers lack the cognitive resources to attend to the situation.

\section{GENERAL DISCUSSION ABOUT RELIGIOUS MARKETING}

Both religious organizations and consumers can benefit from marketing. Our studies indicate, however, that not every religious marketing strategy is equally acceptable; religious marketing may backfire if its market-pricing nature is overly transparent. A compelling demonstration of this effect is the use of a classic market-pricing strategy, outsourcing, to accommodate Mass requests. Outsourcing prayer solves a real problem: the church's inability to cater to all of their members. Because outsourcing prayer is also associated with corporate market-pricing practices, it challenges the church to communally reframe perceptions - a strategy that is especially effective when consumers are less questioning of the church's motives.

\section{PHARMACEUTICAL MARKETING}

Although taboo trade-offs may threaten religious organizations (which have clear communal goals and operate in a sacred world that consumers distinguish from the marketplace; Belk 2005; Belk et al. 1989; Miller 2004), we investigate whether the same effect occurs in the highly lucrative, unquestionably for-profit enterprise of pharmaceutical marketing (Claxton et al. 2007; Lueck 2003). We focus on pharmaceutical pricing because many people believe that "drug companies put profits ahead of people" (Kaiser 2005), a sentiment that is at odds with consumers' preference for health-related endeavors to operate with sensitivity to communal 
norms. For instance, $85 \%$ of undergraduates $(N=40)$ judged a communal focus more appropriate than a market-pricing focus to guide a pharmaceutical company's business plan; only $20 \%$, however, made the same judgment for a software company.

Pharmaceutical pricing justifications provide a timely, real-world investigation of relational framing. Indeed, the industry is highly motivated to reduce the tension between how the industry operates and how consumers believe it ought to operate (Angell 2004). Consumers are often asked to accept higher prices to generate revenue to fund research and development implicit cooperation that satisfies the communal goal of improved public health and well-being. Abbot Laboratories, for example, warded off boycott threats by justifying price increases as necessary to fund new drug research (Harris 2004). Genentech, alternatively, was rebuked for the $\$ 100,000$ price tag of its blockbuster cancer drug, Avastin, when a company executive acknowledged that the price was based on the "value of innovation and the value of new therapies" (Berenson 2006). Thus, we expect that pricing justifications that highlight a company's profit goals, in the communally-preferred domain of health, should be distressing to consumers -- except when a communal-sharing justification is offered.

\section{Study 4: Pharmaceutical Marketing Strategies}

Similar to Study 1, we expected that reactions to pharmaceutical marketing strategies would depend on their underlying relational norm. We contrasted judgments about the acceptability of strategies, which were either market-pricing or communal-sharing in nature, with judgments made for a software company, which consumers expect to act as a for-profit business. Both pharmaceuticals and software are otherwise similar: high research and development costs, low manufacturing and distribution costs, limited patent protection, and heavy demand to 
develop new technology. In an analysis of blue-chip stocks, Microsoft was second only to Pfizer with the highest percentage of capital invested in R\&D (Halperin 2006).

We surveyed an adult sample $(N=1975 ; 61 \%$ female; Median age $=49$ years $)$ to confirm our assertion that consumers believe the pricing of medicine should be based on communalsharing rather than market-pricing principles. A greater proportion of respondents believed that medication should be priced according to need compared to software ( $86 \%$ vs. $56 \%$, respectively; $\left.\chi^{2}=670.5 ; p<.001\right)$.

Method

Eighty nine undergraduates participated in the study for partial course credit. They were randomly assigned to either a pharmaceutical or software condition and told that the company is considering a variety of marketing strategies to "serve, recruit and retain customers." The six marketing strategies are listed in Table 2. We included two pricing-related strategies in the material: the market-pricing strategy was labeled "value-based pricing" and was described, in part, as "selling prices based on the perceived value to the customer, instead of on other traditional factors like production costs or competitor's prices." The communal-sharing strategy was labeled, "ensure access for customers in need," and was described, in part, as "create a special pricing program in which low-income customers can apply for and receive the company's product at a lower cost.” Respondents judged how unacceptable or acceptable each strategy was from an "ethical, moral, or principled standpoint" on a seven-point scale with the end points labeled, "Completely Unacceptable" and "Completely Acceptable."

As a manipulation check, twenty three participants were randomly selected from the same population to judge the strategies' relational focus. They were told that an organization was considering using the strategies (pharmaceutical or software not mentioned). Respondents judged 
whether each strategy was communal (based on cooperative and relationship-building principles) or market focused (based on business and economic principles) on an eight-point scale, with endpoints "Community Focused" and "Market Focused."

\author{
Insert table 2 about here
}

Result

We first examined the perceived focus (communal sharing vs. market pricing) of the strategies on the eight-point response scale (coded one through eight), with higher numbers indicating greater market focus. Three means indicated a market-pricing focus $\left(M^{\prime} \mathrm{s}=6.13-\right.$ $6.65)$ and three indicated a communal-sharing focus $(M ’ \mathrm{~s}=2.48-2.78$; table 2$)$.

Insert figure 3 about here

Judgments of acceptability for the six strategies were coded one through seven, with higher numbers indicating greater acceptance. Panel A of Figure 3 shows the data collapsed into the two relational-focus categories. We created a hierarchical regression model to test the effects of the underlying relational strategy on judgments of acceptability within participants. We first regressed acceptability judgments on the mean focus of the marketing strategy. For each participant, we calculated an unstandardized beta weight for the effect of the strategy on judged acceptability. We then regressed these beta weights on the condition factor (pharmaceutical or software). The model was significant $(F(1,87)=9.5 ; p<.001)$. There was no effect of condition on the intercept $(t(85)=0.1 ; n$.s. $)$, which indicated no difference in acceptability between the pharmaceutical and software conditions. However, there was a significant effect of condition on the slope $(t(87)=3.1 ; p<.01)$, which indicated that the strategy's relational focus had little 
effect on acceptability judgments for the software company but a significant effect for the pharmaceutical company. A mixed-model ANOVA using the two categorized means for each subject confirmed the analysis. The effect of strategy type was significant; communal-sharing strategies were judged more acceptable than market-pricing strategies $(F(1,87)=33.5, p<.001$; $\eta^{2}=.28$ ). Respondents also judged the strategies to be more acceptable for a software than a pharmaceutical company $\left(F(1,87)=10.9, p<.001 ; \eta^{2}=.11\right)$. The main effects, however, were qualified by a significant two-way interaction $\left(F(1,87)=9.4, p<.01 ; \eta^{2}=10\right)$.

The two marketing strategies that referred to pricing decisions are the focus of our subsequent studies. We examined the interaction of "value pricing" and "ensuring access" depending on the type of company (see Figure 3, panel B; $F(1,87)=11.0, p<.001 ; \eta^{2}=.11$ ). The value-pricing strategy was judged more acceptable for a software company than for a pharmaceutical company $(\mathrm{t}(87)=2.8, p<.01 ; d=.58)$, but the reverse occurred for ensuring access to customers $(t(87)=1.9, p<.06 ; d=.38)$.

\section{Discussion}

Our proposed taboo trade-off effect holds in the for-profit context of healthcare. The communal-sharing or market-pricing nature of a marketing strategy had little effect on judgments of acceptability for a software company but a substantial effect for a pharmaceutical company.

Behavioral intentions. Pharmaceutical pricing decisions showed the largest differences in acceptance due to the strategy's relational focus. Thus, we conducted a brief follow-up study to examine consumer backlash against market-pricing versus communal-sharing pricing strategies. Eight hundred and sixty three adults ( $54 \%$ female; median age $=56$ years $)$ were randomly assigned to one of the two pricing strategies from Table 2: value-based pricing (market-pricing) or ensuring accessibility to patients (communal-sharing). After reading about a pharmaceutical 
company that is considering using the (randomly assigned) strategy, participants indicated their agreement to the statement, "I would find it bothersome if the company would engage in such a practice," on a seven-point scale labeled, "Strongly Disagree" and "Strongly Agree." Respondents also judged on a seven-point scale labeled, "Extremely Unlikely" and "Extremely Likely" how likely they were to engage in behaviors due to the company's actions. Items: 1) Complain to a family member, friend, or co-worker about this pharmaceutical company, 2) Ask your doctor to prescribe a generic drug instead of a drug from this company the next time you are sick, and 3) Volunteer for a letter-writing campaign that encourages the government to allow more than one company to produce patented drugs in order to increase competition and lower prices.

The measure of distress was coded one through seven, where higher numbers indicated greater agreement. Respondents were more bothered by the market-pricing strategy $(M=4.97)$ than the communal-sharing strategy $(M=2.65 ; t(861)=17.9, p<.001 ; d=1.26)$. The measures of behavioral intentions were coded one through seven, where higher numbers indicated higher reported intentions to engage in behaviors detrimental to the company. Respondents were more likely to report that they would complain $(M=5.23$ vs. $3.05 ; t(861)=16.6, p<.001 ; d=1.10)$, ask for generic drugs $(M=3.98$ vs. $2.26 ; t(861)=12.8, p<001 ; d=.87)$, and volunteer for a letter-writing campaign ( $M=4.56$ vs. $3.77 ; t(861)=5.5, p<.01 ; d=.38)$ when the value-basedpricing strategy was employed.

\section{Study 5: Justifying Pricing Decisions}

We have shown that reactions to pricing decisions differ between the pharmaceutical industry and the software industry. Next, we test whether relationally reframing market-pricing actions with communal-sharing justifications influences consumer distress in the two industries. 
Although we expect an effect of communal-sharing justification in the pharmaceutical domain, we suspect that the justification will not be as influential in the software domain because the market-pricing goals of the industry are already known and accepted. We use a common justification for the pharmaceutical industry based on findings by Kahneman, Knestch, and Thaler (1986a, 1986b), showing that price increases as the result of pass-through costs (such as research and development) were deemed considered more fair than those based on market considerations (e.g., increased demand).

Method

Two hundred and forty two adult participants $(57 \%$ female; median age $=46$ years $)$ participated in a paid web-based survey. They were randomly assigned to review statements from either a pharmaceutical or software company that lost $\$ 50$ million developing a new product (drug or software program, respectively). The company was considering raising the price of a popular product to make up for the losses (see appendix C). Participants were randomly presented a communal-sharing justification ("in order to continue their ground-breaking research and development of medicines that benefit everyone") or a market-pricing justification ("in order to continue record-breaking profits that benefit investors"). Participants were then presented the statements: "This is a fair pricing strategy" and "I support the use of this pricing strategy," and responded on a seven-point scale from, "Strongly Agree" to "Strongly Disagree."

\section{Results}

Responses were coded one through seven, where higher numbers indicated greater disagreement. The measures were highly correlated $(r=.90 ; p<.001)$, so we computed a composite variable of distress by averaging responses. Panel A of Figure 4 shows the mean 
distress rating by relational justification and company type. The results show a main effect of industry where respondents were more distressed with raising drug prices than software prices, $\left(F(1,238)=7.74, p<.001 ; \eta^{2}=.03\right)$. There was also a main effect of relational frame, $(F(1,238)=$ $\left.5.5, p<.05 ; \eta^{2}=.02\right)$, where respondents were more distressed with the market-pricing justification than with the communal-sharing justification. The main effects were qualified by a significant company by relational-frame interaction, $\left(F(1,238)=5.4, p<.05 ; \eta^{2}=.02\right)$, showing that although communal-sharing justifications reduce consumer distress over price increases for $\operatorname{drugs}\left(M_{\mathrm{MP}}=5.56\right.$ vs. $\left.M_{\mathrm{CS}}=4.61 ; \mathrm{t}(121)=3.2, p<.01 ; d=.58\right)$, the same pattern does not hold true for software $\left(M_{\mathrm{MP}}=4.53\right.$ vs. $M_{\mathrm{CS}}=4.53 ;$ n.s. $)$. Regardless of how the price increase was justified for the software, participants experienced less distress.

\section{Discussion}

Consumers are averse to market-pricing justifications for goods that they feel should be governed by communal rules. Moreover, communal-sharing justifications mitigate distress by making consumers feel that costs are necessary for community well-being. Communally reframed pharmaceutical pricing strategies, furthermore, reduce distress to levels associated with pricing strategies used by the software industry.

$$
\text { Insert figure } 4 \text { about here }
$$

Study 6: Need-based vs. Value-based Drugs

A substantial literature examines the fairness of various pricing strategies as perceived by consumers and finds that fairness is influenced by the product type and the harm caused by high prices (Bolton Warlop and Alba 2003; Campbell 1999; Kahneman et al. 1986a, 1986b). For 
instance, the failure of a firm to reduce prices when costs go down is judged to be more unfair when the product is a drug than when it is furniture (Campbell 2008).

We suspect that the necessity and potentially lifesaving properties of medicine leads consumers to believe that healthcare companies should have a strong communal focus. Next, we set out to test differences in perceptions of value-based pricing strategies for drugs that the public believes should subject to communal or market rules. Only when consumers believe that the drug price should be governed by communal rules should communal-sharing justifications be necessary and effective.

Before the study, we confirmed that consumers believe that the pricing of lifesaving drugs as opposed to life-enhancing drugs should be based on communal-sharing principles. We asked undergraduates $(N=81)$ how a cholesterol-lowering or an anti-wrinkle drug should be priced. A majority (62\%) indicated that an anti-cholesterol drug should be priced according to the needs and means of the patient rather than according to the demands of the marketplace. In contrast, only $28 \%$ made the same judgment for an anti-wrinkle drug.

Method

Two hundred and thirty seven undergraduates were entered into a lottery in exchange for completing a web survey. They reviewed statements from the CEO of a pharmaceutical company who is considering raising prices on a popular drug to make up for R\&D losses on another drug. Participants were randomly assigned to a condition where the price of either an anti-cholesterol or anti-wrinkle drug was raised because of losses on another similar drug. They were also randomly assigned to a condition in which the price increase was accompanied by a communaljustification ("continue researching and developing drugs that benefit everyone") or a marketpricing justification ("ensure revenues and profits for a healthy bottom line"; see appendix D). 
Participants were then presented the statements: "This is a fair pricing strategy" and "I support the use of this pricing strategy," and responded on a seven-point scale labeled, "Strongly Agree" to "Strongly Disagree."

Results

Responses to the measures were coded as in Study 6 and were highly correlated $(r=.88$; $p<.001$ ), so we computed a distress variable by averaging responses. Panel B of Figure 4 shows mean distress rating by justification and medication type. The results show a main effect of medication type, $\left(F(1,233)=18.9, p<.001, \eta^{2}=.08\right)$, in which participants were more distressed at the suggested price increase for the cholesterol drug than for the anti-wrinkle drug. There was also a main effect of relational frame, $\left(F(1,233)=4.9, p<.05 ; \eta^{2}=.02\right)$, indicating that respondents were more distressed by market-pricing justifications than communal-sharing justifications. Consistent with our predictions, the main effects were qualified by a relational frame by drug type interaction in which the communal-sharing justification reduced discomfort for the cholesterol drug $\left(M_{\mathrm{MP}}=4.53\right.$ vs. $\left.M_{\mathrm{CS}}=3.47 ; \mathrm{t}(125)=3.0, p<.05 ; d=.70\right)$ but not for the anti-wrinkle drug $\left(M_{\mathrm{MP}}=3.0\right.$ vs. $M_{\mathrm{CS}}=32.95 ; \mathrm{t}(109)=.3 ;$ n.s. $)$. Regardless of how the price increase was justified for the anti-wrinkle drug, participants experienced identical levels of distress.

Discussion

Communal-sharing justifications do not reduce distress for just any drug - consumers need to believe the drug is truly essential. Relative to a market-pricing justification, the communal-sharing justification assuaged consumer distress due to a price increase of a lifesaving drug but had no effect over the same price increase on a cosmetic drug. 
Study 7: Attenuating Relational Justification Effects

In our final study, we investigate how the differential effectiveness of communal and market justifications might be decreased. Our studies demonstrate that communal justifications are typically preferred over market justifications for increases in drug price. However, when explicitly asked, most consumers acknowledge that the pharmaceutical industry is profit-driven (Kaiser 2005). Given the tension between what consumers want and their recognition of reality, we examine what occurs when consumers consider the intentions of organizations. To do so, we use a persuasion-knowledge priming procedure, which should encourage consumers to probe the veracity of the organization's claims (Campbell and Kirmani 2000; Friestad and Wright 1995). We suspect that when consumers consider the organizations' intentions, the market-pricing justification will be viewed less negatively because the pharmaceutical company is at least honest about its financial obligations. The effectiveness of the communal-sharing justification, by contrast, may in turn decline because it now conflicts with the company's market-pricing obligations.

Method

One hundred and fifty eight participants $(55 \%$ female; median age $=46.5$ years $)$ participated in a paid web-based survey. The study was presented in two seemingly unrelated sections. Participants were randomly assigned to condition based on Campbell and Kirmani (2000). In the condition where participants are primed with persuasion-knowledge, participants are asked to write about how they will persuade a friend to help on a seemingly unpleasant task:

We would like you to make plans. Imagine that you have to bring a task home from work. The task is so big that you are going to need to work on it for most of the weekend - and you still might not get it done. It would be helpful if you can get a friend of yours who is good at the 
task to help you. The friend, however, is very busy, and so you need to persuade him to help. Please list the (several) ways that you would use to make sure that the friend assists you.

In the no-prime condition, the planning task did not involve a persuasion attempt:

We would like you to make plans. Imagine that you have a friend staying with you. He is in town for business and is working on a big task over the weekend. The task is so big that he is going to need to work on it for most of the weekend - and he still might not get it done. You know that you should not disturb him while he is working and so you need to figure out how to do that. Please list the (several) ways that you would use to make sure that you did not disturb your friend while he works.

Participants were thanked for their participation and told they were moving on to a new study (which was presented in a different font and format). Participants then reviewed the pricing strategy scenario from Study 5 and were randomly assigned to either the communal-sharing or market-pricing justifications (see appendix C). Respondents expressed their agreement with three statements designed to measure reaction to the policy: 1) This is a fair pricing strategy, 2) I support the use of this pricing strategy, and 3) I am upset by this pricing strategy. The anchors of the seven-point scales were labeled, "Strongly Agree" and "Strongly Disagree." In the no-prime condition we expected to replicate the previous relational framing effect, but when the prime was present, the difference in reactions to the two justifications would be reduced.

Results

The measures were highly correlated $(\alpha=.81)$ and averaged into a composite of consumer distress (reverse coding the ratings of how upset respondents were). Overall, neither main effect of justification nor that of the request was significant; however, an ANOVA revealed a significant interaction $\left(F(1,514)=4.2, p<.05 ; \eta^{2}=.03\right.$; see panel c of figure 4$)$. Although communal-sharing justifications reduce distress over price increases for $\operatorname{drugs}\left(M_{\mathrm{MP}}=5.86 \mathrm{vs}\right.$. $\left.M_{\mathrm{CS}}=4.97 ; \mathrm{t}(77)=2.6, p<.05 ; d=.60\right)$, the same pattern did not hold true when persuasion knowledge was primed $\left(M_{\mathrm{MP}}=5.21\right.$ vs. $M_{\mathrm{CS}}=5.29 ;$ n.s. $)$. Regardless of how the price increase 
was justified, participants experienced the same amount of distress when primed with persuasion-knowledge.

Discussion

Communal-sharing justifications do not always reduce pricing distress, and nor do market-pricing justifications always increase pricing distress. However, we find a predictable and robust pattern showing that these justifications are polarizing, particularly when consumers are unmotivated to consider an organization's goals. As discussed previously, consumers understand that pharmaceutical companies operate in a for-profit manner but prefer a communal approach. When suspicions are aroused, however, acknowledging a market-pricing orientation may in some ways benefit the organization.

\section{GENERAL DISCUSSION OF PHARMACEUTICAL PRICING}

We tested the effectiveness of relational framing in the domain of healthcare, where market-pricing is often considered a taboo trade-off. Consumers feel greater distress when a pharmaceutical (as opposed to a software company) used commercial marketing. The effect occurs because consumers are more inclined to think that the pharmaceutical industry has a communal obligation to promote well-being. Thus, pharmaceutical industry appeals to accept higher prices for communal benefits are more effective at reducing outrage than software industry appeals. This pattern is limited, however, to drugs that serve life-saving or extending functions, and not to those that serve a cosmetic function. We thus see converging evidence that consumers are sensitive to trade-offs in a predictable way. Consumers react strongly when a taboo trade-off has been committed, but can be assuaged if convinced that their money benefits 
the greater good. Still, when consumers are encouraged to question the organization's motives, the advantage the communal justification has over the market-pricing is eliminated.

\section{GENERAL DISCUSSION}

Marketing commonly adds value to consumer experience and builds brand relationships. However, certain tactics are distressing when consumers believe that organizations, like churches or pharmaceutical companies, ought to act in communal ways. Indeed, religious advertising is often considered unacceptable (McDaniel 1986), pastors are criticized for recruiting youngsters by hosting violent video game nights (Richtel 2007), and consumers are upset by the value-based pricing of life-saving drugs (Berenson 2006).

We draw on Fiske's relational theory $(1991,1992)$ as a framework that delineates rules governing interpersonal and organizational exchanges, and contrast the two most dissonant normative categories: market pricing and communal sharing (McGraw et al. 2003). Communalsharing rules are grounded in deontic principles whereas market-pricing rules are grounded in utilitarianism. Consumers become upset and can even lash out when organizations use marketpricing in communal domains because they see an organization placing profits over people. Consumers, however, do not see taboo trade-offs when market-pricing occurs in secular domains, such as credit unions, software companies and drug companies selling cosmetic drugs.

\section{Relational Framing}

People intuitively grasp relationship norms and view their misapplication as taboo (Fiske and Tetlock 1997). We investigated the effect of disguising taboo trade-offs by relationally framing commercial-marketing strategies as communally beneficial (McGraw and Tetlock 2005). When a religious or healthcare organization uses a communally-focused relational 
justification, consumers are less likely to turn against it.

What influences the effectiveness of relational framing? We began with the assumption that people are motivated to avoid distress and that uncovering taboo trade-offs is effortful and upsetting (Erhlich and Irwin 2005). Of special relevance to relational framing is the tendency to reinterpret situations so that they are not emotionally disruptive (Gross 1998, 2002). Relational framing facilitates the emotion regulation process that, we suspect, will be especially effective when consumers are motivated to accept an organization's justifications. Sympathizers should engage in motivated reasoning that plays up the credibility and moral force of justifications (Kunda 1990; K. M. McGraw 2001). Conversely, critics should generate more counterarguments to neutralize industry-offered justifications (Petty and Cacioppo 1986; Petty, Cacioppo, and Schumann 1983). In a pilot for the outsourcing prayer study, for example, we found that certain consumers were more influenced by communal justifications (Attaway, Boles, and Singley 1997; McDaniel and Burnett 1990). Participants $(N=106)$ read about a church outsourcing prayer to Indian Priests and were randomly assigned to the communal-sharing or market-pricing justification. Religious service attendance moderated the effect of communal-sharing justifications but not market-pricing justifications. That is, respondents who endorsed attending services regularly or occasionally (i.e., the "churched") were more assuaged by the communalsharing justification than those who endorsed never or rarely attending (i.e., the "unchurched"), suggesting that those who care more about the church were more persuaded by the justification.

There are good reasons for suspecting that organizations will often succeed in reframing their taboo trade-offs. Organizations typically have much a stronger interest in concealing taboo trade-offs than individuals have in uncovering them. Organizations also have substantial resources - personnel, capital, and access to media — to craft and communicate effective 
reframing messages. The results of our studies indicate that, insofar as most of the public is not concerned with monitoring church or corporate misconduct at any given moment (most people have more pressing priorities; Campbell and Kirmani 2000; Tuk et al. 2009), organizations have considerable public-relations latitude to justify norm violations. Our findings are also consistent with: (a) Gilbert et al.'s (1990) Spinozan hypothesis that our first reaction to new information is to believe it and that disbelieving requires greater cognitive effort, (b) Langer et al.'s (1978) demonstration that even vacuous accounts are effective in justifying norm violations as long as the timing and context is right, and (c) Tetlock's (1981) demonstration that the self-flattering content of justifications is a more powerful predictor of their efficacy than their plausibility.

\section{Sacred Values}

The reactions to taboo trade-offs due to commercial marketing are consistent with moral psychology research that documents outrage reactions to pitting secular against sacred values (Baron and Spranca 1997; Rozin et al. 1999; Haidt 2001; Rai and Fiske 2011; Tetlock et al. 2000). Most people, atheists included, insist that certain values are sacred and that it is unacceptable to mix them with secular values like money (Durkheim 1925). Sacredness qualifies as a distinct normative standard of conduct, despite the variation in what things various groups hold sacred and how they uphold their values (Aberle et al. 1950; Belk et al. 1989).

A deep tension exists between what people consider ideologically off-limits and the reality that we live in a world of finite resources in which dispassionately making trade-offs is a defining feature of rationality (Bartels 2008). There are strong cases for expanding market mechanisms into domains where many feel they do not belong: organs (Barnett et al. 1992), adoptions (Landes and Posner 1978), pollution credits (Hahn 1989), and prediction markets for terrorism futures (Weber and Tetlock 2003). These arguments lead to anxiety about the 
legitimacy of institutions (Shiller, Boycko, and Korobov 1991; Sondak and Tyler 2007) and a desire to escape markets (Kozinets 2002). Our results identify one method of justifying the expansion of market-pricing into new domains; a method that can, of course, be achieved by invoking the "greater good."

\section{Limitations and Future Directions}

Churches and pharmaceutical companies are compelling case studies because of widespread anecdotal evidence that their commercial marketing is distressing to consumers. Future research should examine our effects in other domains. For example, companies that provide strong need-based products and services with inelastic demand (e.g., utilities, hospitals, oil companies) should be subject to backlash from commercial marketing — and may already be experimenting with ways to reframe their inherent taboo trade-offs.

At the outset we suggested that commercial marketing and communal justifications have important implications for consumer goals. Although we find evidence of shifting intentions to disengage from religious activities (Study 1) and to lobby against patent restrictions (Study 4), future work would benefit from tests of behavioral follow-through.

Although our studies use relational justifications inspired by naturally occurring cases in the marketplace, our studies could be criticized from a stimulus sampling perspective: our effects may have been overly influenced by the particular justifications that we selected. Communal justifications may have other mediators besides moral distress that are worthy of future investigation. For instance, communal-sharing justifications may signal an organization that is warm and caring, which could drive the justification's impact (Aaker, Vohs, and Mogilner 2010). We can partially dismiss this explanation by pointing to the interaction in Study 5 , in which communal-sharing justifications had no effect for a software company. 
The use of hybrid justifications is a particularly interesting area to examine, especially given the results of Study 7 and research on the effectiveness of two-sided arguments in checking counter-arguing (Lumsdaine and Janis 1953). Consider this quote from Billy Tauzin, president of $P h R M A$, a pharmaceutical industry lobbying organization (www.phrma.org)

“... truth is that we are - as an industry - focused on one thing: the patient. Granted, we're a business - a pretty darn big business. But we're a business OF people working FOR people. We make lives better through better health.” [Emphasis original.]

Research should explore whether these sorts of complex justifications, that highlight both the market pricing means and the communal objectives of the organization, are effective even when consumers have been alerted to persuasive intent. Indeed, if anyone has rightly identified the right formula, it is likely to be a lobbying organization. 


\section{APPENDIX A}

Stimulus materials presented to respondents in Study 2.

The Catholic Church has a long-standing practice that allows for a Mass to be said in honor of someone who has died, is ill or has some other special need. The person requesting the Mass customarily offers about $\$ 20$ as a donation for each Mass.

Note: A Mass is a Catholic service where there are Biblical readings, sermons, and offerings. A Mass may or may not be attended by members of the congregation or by the person requesting it.

The Catholic Church in the U.S. cannot always keep up with requests for Masses by their local congregations. Demand is too high and the supply of priests is too low. Because a single Mass is dedicated to a single individual, there is often a long waiting list to have a requested Mass said. Suppose the Catholic Church, however, has many priests available to fulfill this need in rural congregations in India, and these Masses can be conducted rather quickly. Consequently, the Catholic Church in the U.S. has been sending prayer requests to these other Churches. The practice is mutually beneficial to both Churches. The local congregation keeps some of the donation and is able to fulfill the needs of its congregation, and the Church receiving the prayer request keeps the remainder of the donation to help with expenses. 


\section{APPENDIX B}

Stimulus materials presented to respondents in Study 3.

The Catholic Church allows for a Mass to be dedicated to someone in need. The person requesting the Mass customarily offers a donation $(\sim 20)$ with the request.

Note: A Mass is a Catholic service where there are Biblical readings, sermons, offerings, and prayer. The requested Mass may or may not be attended by members of the congregation or by the person requesting $i t$.

The Catholic Church in the U.S. cannot always keep up with Mass requests by their local congregations. However, the Church has many priests in India who are available to fulfill the requests in a timely manner. Consequently, the Catholic Church in the U.S. has been sending these prayer requests to India. The U.S. Church keeps some of the donation and sends a portion to the Church in India. 


\section{APPENDIX C}

Stimulus materials presented to respondents in Study 5 and 7.

\section{Pharmaceutical company/Communal-sharing justification}

A small promising pharmaceutical company suffers a $\$ 50$ million loss developing a new drug. In order to continue their ground-breaking research and development of medicines that benefit everyone, the company is considering making up for the loss by raising the price of a popular medication.

\section{Pharmaceutical company/Market-pricing justification}

A small promising pharmaceutical company suffers a $\$ 50$ million loss developing a new drug. In order to continue achieving record-breaking profits and revenues that benefit investors, the company is considering making up for the loss by raising the price of a popular medication.

\section{Software company/Communal-sharing justification}

A small promising software company suffers a $\$ 50$ million loss developing a new software program. In order to continue their ground-breaking research and development of software that benefit everyone, the company is considering making up for the loss by raising the price of a popular software program.

\section{Software company/Market-pricing justification}

A small promising software company suffers a $\$ 50$ million loss developing a new software program. In order to continue achieving record-breaking profits and revenues that benefit investors, the company is considering making up for the loss by raising the price of a popular software program. 


\section{APPENDIX D}

Stimulus materials presented to respondents in Study 6.

\section{Communal-sharing justification}

A large pharmaceutical company reports a $\$ 50$ million loss on the research and development of a new cholesterol lowering medication. The loss occurred because a rival drug company has just received approval for their [anti-wrinkle drug/cholesterol lowering drug], which is both more effective and has fewer side effects than the other drug. A $\$ 50$ million loss is not uncommon during research and development but in order to continue bringing safe and effective drugs to the public such losses must be made up for elsewhere. The CEO of the company thinks that one way to minimize the loss is to raise prices on a drug that is in high demand. Specifically, his company can recoup their $\$ 50$ million loss by raising the price of their highly successful and popular [cholesterol lowering medication/anti-wrinkle treatment]. In doing that the company ensures that research and development continues for drugs that benefit everyone.

\section{Market-pricing justification}

A large pharmaceutical company reports a $\$ 50$ million loss on the research and development of a new [anti-wrinkle treatment/cholesterol lowering medication]. The loss occurred because a rival drug company has just received approval for their [anti-wrinkle drug/cholesterol lowering drug], which is both more effective and has fewer side effects than the other drug. A $\$ 50$ million loss is not uncommon during research and development but in order to continue bringing safe and effective drugs to the public such losses must be made up for elsewhere. The $\mathrm{CEO}$ of the company thinks that one way to minimize the loss is to raise prices on a drug that is in high demand. Specifically, his company can recoup their $\$ 50$ million loss by raising the price of their highly successful and popular [cholesterol lowering medication/anti-wrinkle treatment]. In doing that the company ensures revenues and profits for a healthy bottom line. 


\section{References}

Aaker, Jennifer, Susan Fournier, and S. Adam Brasel (2004), "When Good Brands Do Bad," Journal of Consumer Research, 31 (June), 1-16.

Aaker, Jennifer L., Kathleen D. Vohs, Cassie Mogilner (2010), "Non-Profits Are Seen as Warm and For-Profits as Competent: Firm Stereotypes Matter," Journal of Consumer Research, 37, (August), $224-237$.

Aberle, D.F., A.K. Cohen, A.K. Davis, M.J. Levy Jr., and F.X. Sutton (1950), “The Functional Prerequisites of a Society," Ethics, 60 (2), 60-111.

Aggarwal, Pankaj (2004), "The Effects of Brand Relationship Norms on Consumer Attitudes and Behavior," Journal of Consumer Research, 31 (June), 87-101.

Angell, Marcia (2004), The Truth About Drug Companies, New York, NY: Random House.

Attaway, Jill S., James S. Boles, and Rodger B. Singley (1997), “Exploring Consumers' Attitudes Toward Advertising by Religious Organizations," The Journal of Marketing Management, 13 (Fall/Winter), 71-83.

Barnett, Andrew H., Roger D. Blair, and David L. Kaserman (1992), "Improving Organ Donation: Compensation Versus Markets," Inquiry, 29 (3), 372-78.

Baron, Jonathan and Mark Spranca (1997), "Protected Values," Organizational Behavior and Human Decision Processes, 70 (April), 1-16.

Bartels, Daniel M. (2008), “Principled Moral Sentiment and the Flexibility of Moral Judgment and Decision Making," Cognition, 108 (March), 381-417.

Beattie, Rich (2005), "Bed, Breakfast, Gas: Inns Try to Coax Their Guests to Keep On Driving," New York Times, September 30.

Belk, Russell (2005). "Exchange Taboos from an Interpretive Perspective," Journal of Consumer 
Psychology, 15 (January), 16-21.

Belk, Russell W., Melanie Wallendorf, and John F. Sherry (1989), "The Sacred and the Profane in Consumer Behavior: Theodicy on the Odyssey," Journal of Consumer Research, 16 (June), 1-38.

Berenson, Alex (2006), “A Cancer Drug Shows Promise, at a Price That Many Can't Pay,” New York Times, February 15.

Bolton, Lisa, Luk Warlop, and Joseph W. Alba (2003), “Consumer Perceptions of Price (Un)Fairness,” Journal of Consumer Research, 29 (March), 474-91.

Campbell, Margaret C. (1999) "Perceptions of Price Unfairness: Antecedents and Consequences," Journal of Marketing Research, 36 (May), 187-99. (2008), "The Role of Inferences of Impact on Perceptions of Price (Un)Fairness," in Advances in Consumer Research Vol. 35, eds. Angela Y. Lee and Dilip Soman, Duluth, MN : Association for Consumer Research, Pages: 253-56.

Campbell, Margaret, and Amna Kirmani (2000), “Consumers’ Use of Persusasion Knowlodge: The Effects of Accessibility and Cognitive Capacity on Perceptions of an Influence Agent," Journal of Consumer Research, 27 (June), 69-83.

Cialdini, Robert B. (2001), Influence: Science and Practice. Boston: Allyn \& Bacon. Claxton, Gary, Bianca DiJulio, Benjamin Finder, Eric Becker, Samantha Hawkins, Jeremy Pickreign, Heidi Whitmore, and Jon Gabel (2007), Employer Health Benefits, (Menlo Park: Henry J. Kaiser Family Foundation; Chicago: Health Research and Educational Trust) http://www.kff.org/insurance/7672/.

Drucker, Peter F. (1989), "What Business Can Learn from Nonprofits," Harvard Business Review, 67 (July-August), 88-93. 
Durkheim, Emile (1925/1976), The Elementary Forms of the Religious Life, London: Allen and Unwin.

Ehrich, Kristine R. and Julie R. Irwin (2005), "Willful Ignorance in the Request of Product Attribute Information," Journal of Marketing Research, 42 (August) 266-77.

Fiske, Alan P. (1991), Structures of Social Life: The Four Elementary Forms of Social Relations, New York, NY: Free Press. (1992), “The Four Elementary Forms of Sociality: Framework for a Unified Theory Social Relations," Psychological Review, 99 (October), 689-723.

Fiske, Alan P. and Philip Tetlock (1997), “Taboo Trade-offs: Reactions to Transactions that Transgress the Domain of Relationships," Political Psychology, 18 (June), 255-97.

Fournier, Susan (1998), "Consumers and Their Brands: Developing Relationship Theory in Consumer Research" Journal of Consumer Research 24 (March), 343-73

Friestad, Marian and Peter Wright (1995), "Persuasion knowledge: lay people's and researchers' beliefs about the psychology of advertising," Journal of Consumer Research, 22 (June), $62-74$

Gilbert, Daniel. T., and J. Gregory. Hixon, (1991), “The trouble of thinking: Activation and application of stereotypic beliefs," Journal of Personality and Social Psychology, 60, $509-517$.

Gilbert, Daniel T., Douglas S. Krull, and Patrick S. Malone (1990), "Unbelieving the Unbelievable: Some Problems in the Rejection of False Information," Journal of Personality and Social Psychology, 59 (October), 601-13.

Graham, Kevin (2005), “Church's Hummer Prize too Worldly?,” St. Petersburg Times. January 10. 
Gregson, Nigel, Keiron Sparrowhawk, Josephine Mauskopf, and John Paul (2005), “Pricing Medicines: Theory and Practice, Challenges and Opportunities," Nature Reviews. 4 (Feburary), 121-30.

Gross, James J. (1998), “Antecedent and Response-focused Emotion Regulation: Divergent Consequences for Experience, Expression, and Physiology," Journal of Personality and Social Psychology, 74 (1), 224-37. (2002), "Emotion Regulation: Affective, Cognitive, and Social Consequences," Psychophysiology, 39, 281-91.

Haidt, Jonathan (2001), “The Emotional Dog and its Rational Tail: A Social Intuitionist Approach to Moral Judgment," Psychological Review, 108 (4), 814-34.

Haidt, Johnathan and S. Algoe (2004), "Moral Amplification and the Emotions that Attach Us to Saints and Demons," in Handbook of Experimental Existential Psychology, eds. Jeff Greenberg, Sander Koole, Tom Pyszczynski, New York, NY: Guildford, 322-35.

Hahn, R.W. (1989), “Economic Prescriptions for Environmental Problems: How the Patent Followed the Doctor's Orders," Journal of Economic Perspectives, 3 (Spring), 95-114.

Halperin, Alex (2006), "Does big R\&D Mean Big Returns? We Check whether Heavy Research and Development Spending Translates into Stock Performance for Five Companies on the Cutting Edge," Business Week, November 22.

Harris, Gardiner (2004), "Price of AIDS Drug Intensifies Debate on Legal Imports," New York Times, April 14.

Haslam, Nick (2004), Relational Models Theory: A Contemporary Overview, Mahway, NJ: Erlbaum. 
Homburg, Christian, Wayne D. Hoyer, and Nicole Koschate (2005), “Customers' Reactions to Price Increases: Do Customer Satisfaction and Perceived Motive Fairness Matter?” Journal of the Academy of Marketing Science, 33 (Winter), 36-49.

Johar, Gita Venkataramani (2005), "The Price of Friendship: When, Why, and How Relational Norms Guide Social Exchange Behavior," Journal of Consumer Psychology, 15 (January), 22-7.

Kahn, Barbara E. (2005), "The Power and Limitations of Social Relational Framing for Understanding Consumer Decision Processes: Comment," Journal of Consumer Psychology, 15 (January), 28-34.

Kahneman, Daniel, Jack L. Knetsch, and Richard Thaler (1986a), "Fairness as a Constraint on Profit Seeking: Entitlements in the Market," The American Economic Review, 76 (September), 728-41.

Kahneman, Daniel, Jack Knetsch, and Richard Thaler (1986b), "Fairness and the Assumptions of Economics," Journal of Business, 59 (October), 285-300.

Kaiser poll (2005); (http://www.kff.org/healthpollreport/feb_2005/index.cfm).

Kenneson, Philip and James L. Street (1997), Selling Out the Church: The Dangers of Church Marketing, Nashville, TN: Abingdon.

Kozinets, Robert V. (2002), “Can Consumers Escape the Market? Emancipatory Illuminations from Burning Man,” Journal of Consumer Research, 29 (June), 20-38.

Krull, Douglas. S. (1993). "Does the Grist Change the Mill? The Effect of Perceiver's Inferential Goal on the Process of Social Inference," Personality and Social Psychology Bulletin, 19, $340-348$.

Kunda, Ziva. (1990), "The Case for Motivated Reasoning," Psychological Bulletin, 108 
(November), 480-98.

Landes, Elisabeth M., and Richard A. Posner, (1978). “The Economics of the Baby Shortage,” The Journal of Legal Studies, 7 (June), 323-48.

Langer, Ellen J., Arthur Blank, and Benzion Chanowitz (1978), "The Mindlessness of Ostensibly Thoughtful Action: The Role Of 'Placebic Information in Interpersonal Interaction'," Journal of Personality and Social Psychology, 36 (June), 635-42.

Luce, Mary Frances, James R. Bettman, and John W. Payne (1997), "Choice Processing in Emotionally Difficult Decisions," Journal of Experimental Psychology: Learning, Memory, and Cognition, 23 (March), 384-405.

Lueck, Sarah (2003), "Drug Prices Far Outpace Inflation," The Wall Street Journal, July 10, D2. Lumsdaine, Arthur. A., \& Irving L. Janis (1953), "Resistance to “Counterpropaganda” Produced by One-sided and Two-sided "Propaganda" Presentations. Public Opinion Quarterly, 17, $311-318$.

Luo, Michael (2006). "With Yoga, Comedy and Parties, Synagogues Entice Newcomers ," New York Times, April 4.

March, James (1994), A primer on decision making, New York, NY: Free Press.

McCullough, Michael E. and Brian L. B. Willoughby (2009), "Religion, Self-Regulation, and Self-Control: Associations, Explanations, and Implications," Psychological Bulletin, 135 (1), 69-93.

McDaniel, Stephen W. (1986), "Church Advertising: Views of the Clergy and General Public," Journal of Advertising, 15 (March), 24-9.

McDaniel, Stephen W. and John J. Burnett, (1990), "Consumer Religiosity and Retail Store Evaluative Criteria,” Journal of the Academy of Marketing Science, 18 (March), 101-112. 
McGraw, A. Peter and Philip E. Tetlock (2005), “Taboo Trade-offs, Relational Framing and the Acceptability of Exchanges," Journal of Consumer Psychology, 15, (January) 2-15.

McGraw, A. Peter, Philip E. Tetlock, and Orie V. Kristel (2003), “The Limits of Fungibility: Relational Schemata and the Value of Things," Journal of Consumer Research, 30 (September), 219-29.

McGraw, Kathleen M. (2001), "Political Accounts and Attribution Processes," in Citizens and Politics: Perspectives from Political Psychology, ed. James Kuklinski, New York, NY: Cambridge University.

Miller, Vincent J. (2004), Consuming religion: Christian faith and practice in a consumer Culture, New York, NY: Continuum.

Nowlis, Stephen M., Barbara E. Kahn, and Ravi Dhar (2002), "Coping with Ambivalence: The Effect of Removing a Neutral Option on Consumer Attitude and Preference Judgments," Journal of Consumer Research, 29 (December), 319-34.

Petty, Richard E., and John T. Cacioppo (1986), Communication and Persuasion: Central and Peripheral Routes to Attitude Change, New York, NY: Springer-Verlag.

Petty, Richard E., John T. Cacioppo, and David Schumann (1983), "Central and Peripheral Routes to Advertising Effectiveness: The Moderating Role of Involvement," Journal of Consumer Research, 10 (September), 135-46.

Rai, Saritha (2004), "Short On Priests, U.S. Catholics Outsource Prayers to Indian Clergy," New York Times, June 13, 1-15.

Rai, Tage Shakti., and Alan P. Fiske (2011), "Moral Psychology Is Relationship Regulation: Moral Motives for Unity, Hierarchy, Equality, and Proportionality," Psychological Review, 118 (January), 57-75. 
Richtel, Matt (2007), "Thou Shall Not Kill, Except in a Popular Video Game at Church," New York Times, October 7, A1.

Rozin, Paul, Laura Lowery, Sumio Imada, and Jonathan Haidt, (1999), “The CAD Triad Hypothesis: A Mapping between Three Moral Emotions (Contempt, Anger, Disgust) and Three Moral Codes (Community, Autonomy, Divinity)," Journal of Personality and Social Psychology, 76 (April), 574-86.

Schlesinger, Leonard A., and James Mellado (1991), Willow Creek Community Church, Cambridge, MA: Harvard Business School.

Shawchuck, Norman, Philip Kotler, Bruce Wrenn, and Gustav Rath (1992), Marketing for Congregations: Choosing to Serve People More Effectively, Nashville, TN: Abingdon.

Shiller, Robert J., Maxim Boycko, and Vladimir Korobov (1991), "Popular Attitudes toward Free Markets: The Soviet Union and the United States Compared," American Economic Review, 81 (June), 385-400.

Sondak, Harris and Tom R. Tyler (2007), "How Does Procedural Justice Shape the Desirability of Markets?" Journal of Economic Psychology, 28 (January), 79-92.

Symonds, William C. (2005), "Earthly Empires: How Evangelical Churches are Borrowing from the Business Playbook," BusinessWeek, May 23, 79-88.

Tetlock, Philip E. (1981), "Pre- to Post-Election Shifts in Presidential Rhetoric: Impression Management or Cognitive Adjustment?” Journal of Personality and Social Psychology: Attitudes and Social Cognition, 41(August), 207-12.

(2002), "Social Functionalist Frameworks for Judgment and Choice: People as Intuitive Politicians, Theologians, and Prosecutors.” Psychological Review, 109 (July), $451-71$. 
Tetlock, Philip E., Orie V. Kristel, Beth Elson, Melanie Green, and Jennifer Lerner (2000), “The Psychology of the Unthinkable: Taboo Trade-offs, Forbidden Base Rates, and Heretical Counterfactuals," Journal of Personality and Social Psychology, 78 (May), 853-70.

Tetlock, Phillip E., Randall Peterson and Jennifer Lerner (1996), "Revising the Value Pluralism Model: Incorporating Social Content and Context Postulates," in Ontario Symposium on Social and Personality Psychology: Values. ed. Clive Seligman, James Olson, and Mark Zanna, Hillsdale, NJ: Erlbaum, 25-51.

Tuk, Mirjam, Peeter Verlegh, Ale Smidts and Daniel Wigboldus (2009), "Sales and Sincerity: The Role of Relational Framing in Word-of-Mouth Marketing.” Journal of Consumer Psychology, 19 (January), 38-47.

Wan, Lisa C., Michael K. Hui, and Robert S. Wyer (2011), “The Role of Relationship Norms in Response to Service Failures," Journal of Consumer Research, 38 (August).

Weber, Steven and Philip E. Tetlock, (2003), "Futures Trading and the Internet," New York Times, Aug11, Editorial.

Zhao, Xinshu, John G. Lynch Jr. and Qimei Chen (2010), “Reconsidering Baron and Kenny: Myths and Truths About Mediation Analysis," Journal of Consumer Research, 37 (August), 197-206.

Zhong, Chen-Bo and Katie Liljenquist (2006), "Washing Away Your Sins: Threatened Morality and Physical Cleansing," Science, 313 (Sept), 1451-52. 
Table 1: Marketing strategies presented in study 1. Mean focus (Focus) indicates the degree that the strategy was judged to be market-pricing (MP), mixed, or communal-sharing (CS). Higher numbers indicate a greater MP focus. Acceptability ratings are shown for the Credit Union (Credit) and Church (Church) conditions. Higher numbers indicate greater acceptance of the strategy.

MP-focused Strategies
Institute a rebranding plan. For example, hire a consulting company to analyze the strengths and
weaknesses of the organization and its image. Make changes to the organization's name, logo,
building, and enact marketing communications based on the analysis.

Establish superiority of the organization through advertising. For example engage television, radio, newspaper, or outdoor advertising that highlights excellent aspects of the organization in order to spread the word to current and potential members.

Hire a celebrity endorser. For example, pay someone that potential members are familiar with to be the spokesperson for the organization. This person will be featured in print and television advertisements, as well as speaking engagements.

\section{Mixed-focused Strategies}

Affiliate with other similar organizations. For example, find similar, like-minded organizations and build coalitions that pool resources and allow members to utilize the other organizations resources.

Host a fair to show organization's offerings. For example, invite members and potential members to tell them about the services the organization provides. Serve food and drink, and have the organization's leadership present to meet members.

Institute a "tell your family or friend" campaign. For example, ask current members reach out to people who are close to them to inform them about the organization and how it can serve their needs.

\section{CS-focused Strategies}

Create open-enrollment classes and workshops. For example, invite members and non-members to classes that provide relevant information about issues that are related to the organization's mission. The classes will be taught by leaders or members in the organization.

Create an online forum for members. For example, include online message boards and a blog on the organization's webpage in which members can communicate with one another and help address issues related to the organization's mission.

Establish services for members' children. For example, provide free child care while members visit the organization. Also, build a playground on the grounds so children have something to do while adults are involved with the organization.

\begin{tabular}{|c|c|c|}
\hline Focus & Credit & Church \\
\hline 6.75 & 5.53 & 3.47 \\
\hline 6.50 & 5.47 & 4.65 \\
\hline 6.31 & 4.47 & 3.06 \\
\hline Focus & Credit & Church \\
\hline 4.44 & 5.12 & 5.14 \\
\hline 4.38 & 5.67 & 5.47 \\
\hline 3.69 & 5.00 & 4.65 \\
\hline Focus & Credit & Church \\
\hline 2.81 & 5.47 & 5.18 \\
\hline 2.56 & 5.40 & 5.76 \\
\hline 2.06 & 5.67 & 5.82 \\
\hline
\end{tabular}


Table 2 Marketing strategies presented in Study 4. Mean focus (Focus) indicates the degree that the strategy is market-pricing (MP), mixed, or communal-sharing (CS). Higher numbers indicate a greater MP focus. Acceptability ratings are shown for the software company (Software) and pharmaceutical company (Pharma) conditions. Higher numbers indicate greater acceptance of the strategy.

\section{MP-focused Strategies}

Institute a rebranding plan. For example, hire a consulting company to analyze the strengths and weaknesses of the organization and its image. Make changes to the organization's name, logo, building, and enact marketing communications based on the analysis.

Engage in value-based pricing. Engage in value-based pricing. For example, set selling prices based on the perceived value to the customer, instead of on other traditional factors like production costs or competitor's prices. The company chooses a price that takes into account how much consumers value the product in order to maximize the company's profit and competitive advantage.

Hire a celebrity endorser. For example, pay someone that potential members are familiar with to be the spokesperson for the organization. This person will be featured in print and television advertisements, as well as speaking engagements.

CS-focused Strategies

Create an online forum for members. For example, include online message boards and a blog on the organization's webpage in which members can communicate with one another and help address issues related to the organization's mission.

Create open-enrollment classes and workshops. For example, invite members and non-members to classes that provide relevant information about issues that are related to the organization's mission. The classes will be taught by leaders or members in the organization.

Ensure access for customers in need. For example, create a special pricing program in which lowincome customers can apply for and receive the company's product at a lower cost. The program would also help those customers with informational support about the company's products.

\begin{tabular}{|c|c|c|}
\hline Focus & Software & Pharma \\
\hline 6.6 & 6.39 & 5.86 \\
\hline
\end{tabular}

$\begin{array}{lll}6.26 & 4.87 \quad 3.86\end{array}$

$\begin{array}{lll}6.13 & 6.0 \quad 5.00\end{array}$

\begin{tabular}{|c|c|c|}
\hline Focus & Software & Pharma \\
\hline 2.78 & 6.67 & 6.19 \\
\hline 2.83 & 6.38 & 5.80 \\
\hline 2.48 & 5.26 & 5.91 \\
\hline
\end{tabular}


Figure 1. Mean acceptability ratings plotted for a credit union or church in Study 1. Separate bars show acceptability ratings for the judged relational focus of the marketing strategy (Community focused; Market/Community; and Market focused). Error bars represent one standard error above the mean.

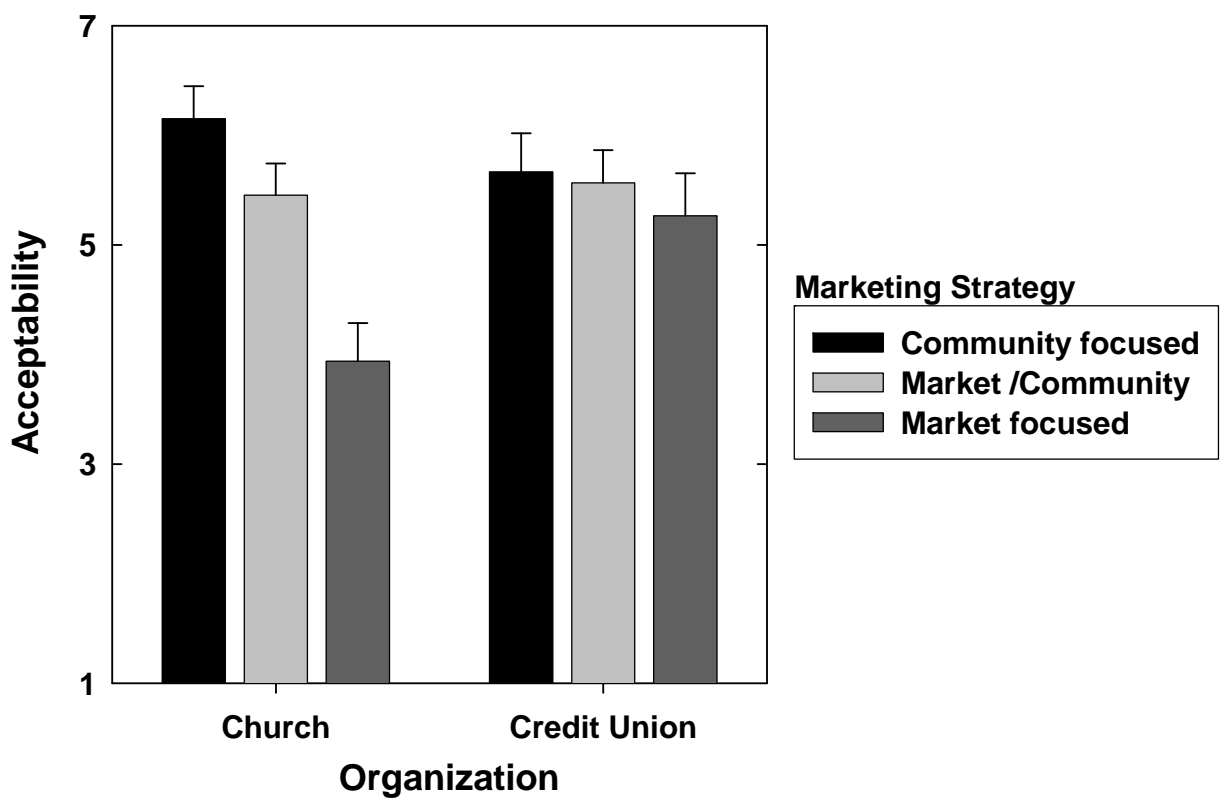


Figure 2. Mean distress ratings caused by a church outsourcing prayer plotted for the communalsharing (black bars) or market-pricing (grey bars) justification in Study 3. The effects are shown separately for whether participants were under low or high cognitive load. Error bars represent one standard error above the mean.

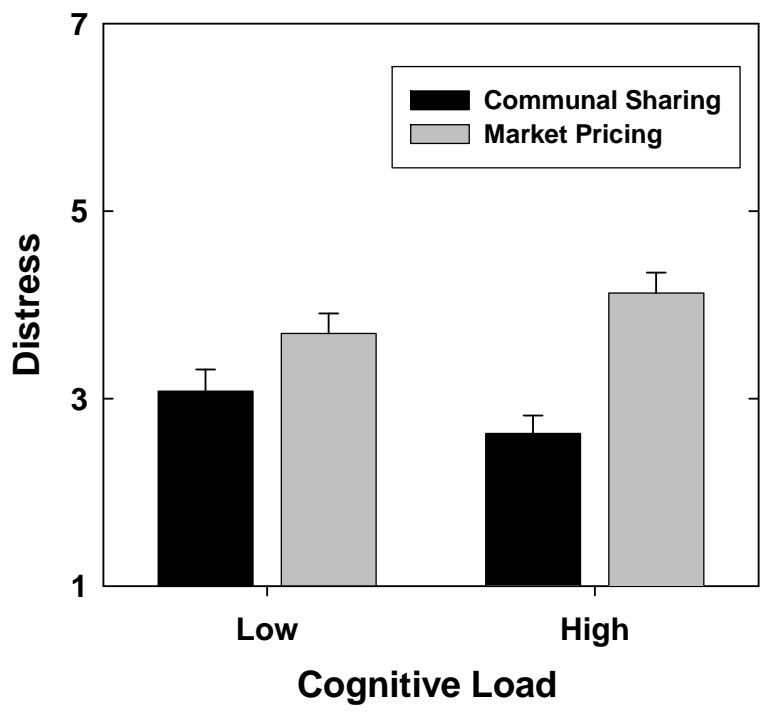


Figure 3. Panel A shows mean acceptability ratings plotted for a software company or a pharmaceutical company in Study 4. Separate bars show a communal-sharing (black bars) or market-pricing (grey bars) focus. Panel B shows mean acceptability ratings for a software company or a pharmaceutical company. Separate bars show the ensuring access focus (black bars) or value pricing focus (grey bars). Error bars represent one standard error above the mean.

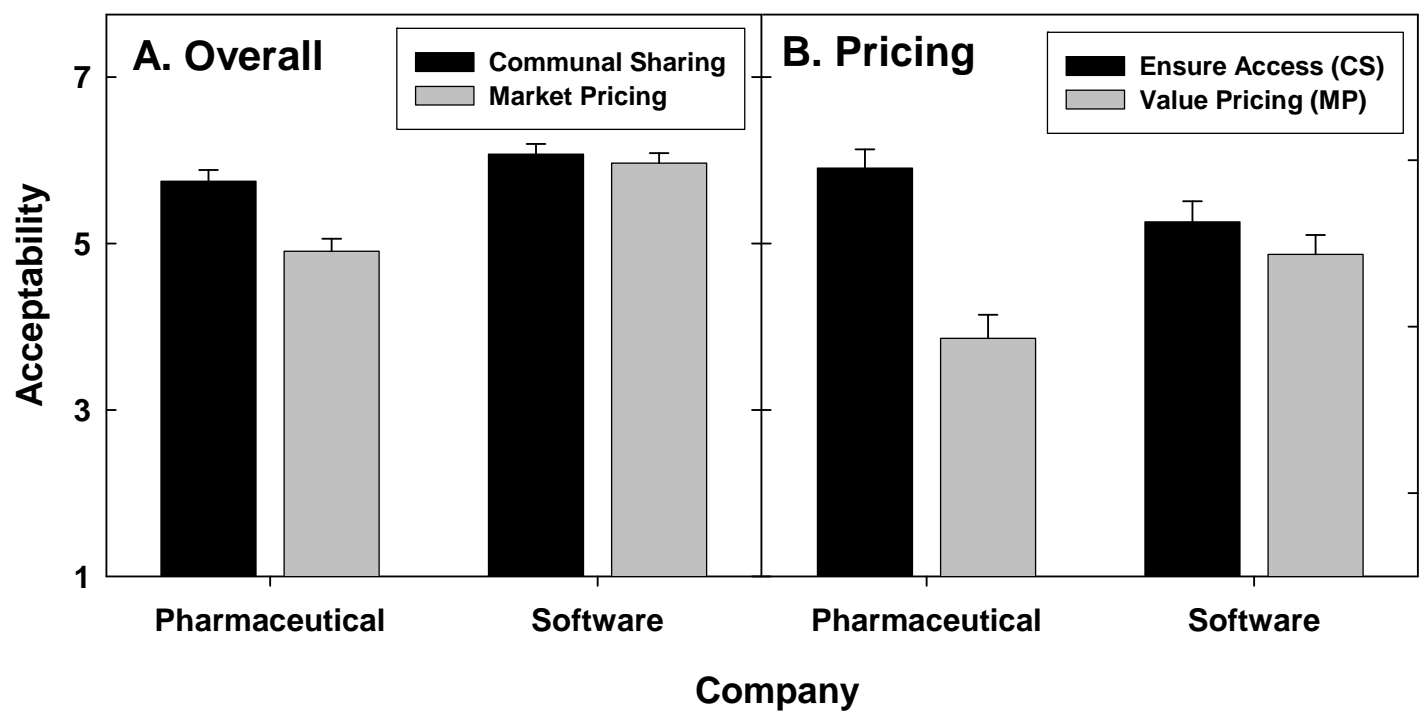


Figure 4. Separate bars depict a communal-sharing (black bars) or market-pricing (grey bars) justification. Panel A shows mean distress with the companies pricing strategy as a function of the justification (market-pricing or communal sharing) in Study 5. The communal-sharing justification significantly reduces distress for the pharmaceutical condition. However, for software the justification condition had a non significant-effect on distress. Panel B shows mean distress with the companies pricing strategy as a function of the justification (market pricing or communal sharing) in Study 6. The communal-sharing justification significantly reduces distress for the anti-cholesterol drug (cholesterol) condition. However, for the anti-wrinkle drug (wrinkle) the justification condition had a non significant effect on distress. Panel $\mathrm{C}$ shows mean distress with the companies pricing strategy plotted for the communal-sharing or market-pricing justification in Study 7. Persuasion knowledge was either primed or not in the study. The communal-sharing justification significantly reduces distress when persuasion knowledge is not primed. However, when persuasion knowledge is primed there is no difference between justification conditions. Error bars represent one standard error above the mean.

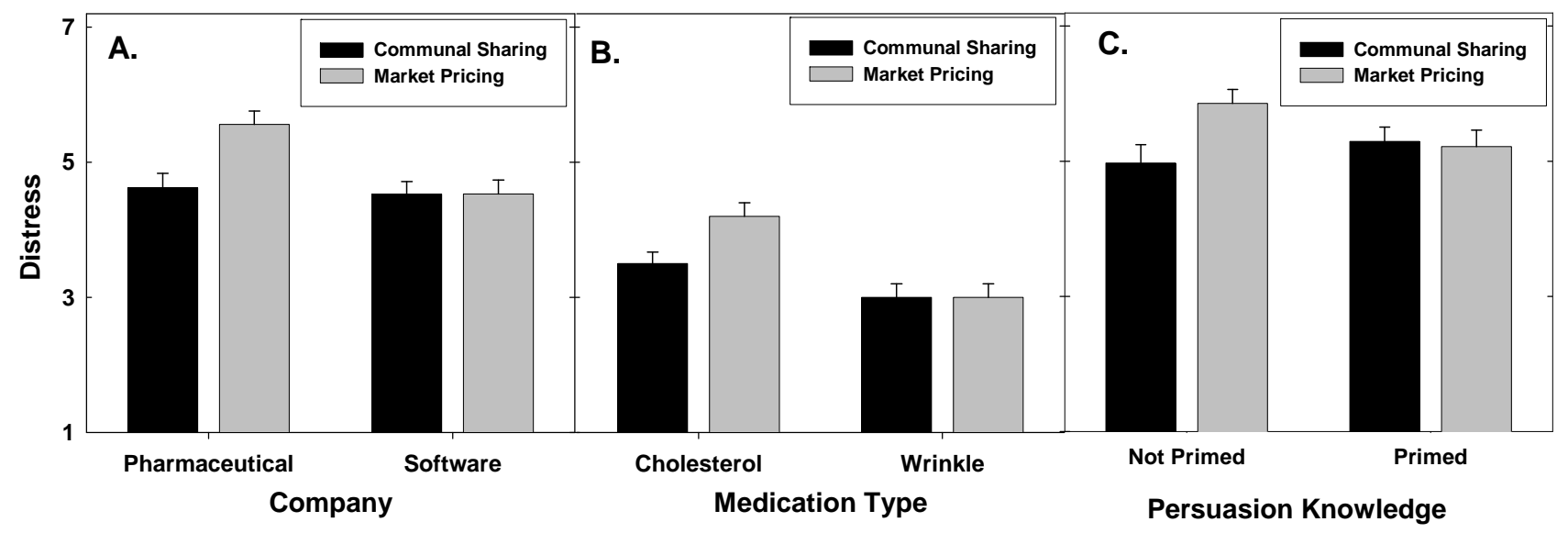

